\title{
Javanese Language Preservation in the Global Era: Determining Effective Teaching Methods for Elementary School Students
}

Lusia Neti Harwati*

Faculty of Cultural Sciences, Brawijaya University, Jalan Veteran Malang, East Java, Indonesia

Corresponding Author: Lusia Neti Harwati, E-mail: lusianeti@ub.ac.id

\section{ARTICLE INFO}

Article history

Received: March 14, 2018

Accepted: May 21, 2018

Published: August 31, 2018

Volume: 9 Issue: 4

Advance access: July 2018

Conflicts of interest: None

Funding: The research is financed by DPP/SPP 2016, Faculty of Cultural

Sciences, Brawijaya University

\section{Key words:}

Sociolinguistics,

Social Change,

Society,

Speech Community,

Globalization,

Javanese Language

\begin{abstract}
Previous studies on Javanese language emphasized more on the use of this local language in certain communities and ignored the importance of teaching and learning at an elementary school level in order to preserve the language. The purpose of this study was to describe the lives of the participants, collect and tell stories about their lives, and then write narratives of their experiences. The data were gathered through the collection of stories, reporting individual experiences, and discussing the meaning of those experiences for the participants by proposing a research question: what is the story of the teachers who tried to preserve Javanese language in the global era? A narrative research design, sociolinguistics, and social change as theories were applied in order to understand teachers' point of view on globalization and the importance of preserving Javanese language. Purposeful sampling was used and two teachers were chosen as participants. The data gathered were then analyzed through three steps, namely code the data, description, and interpretation. There are two findings that can be summarized. Firstly, the interviewees perceived the challenges in teaching Javanese language as an opportunity to be more creative. Secondly, in the attempt to preserve and promote Javanese language and culture, they were fully supported by the school principal as well as the local government. It can be concluded that knowledge of effective teaching strategies is vital in terms of providing an indepth understanding of how elementary schools can deal with the possible negative impacts of globalization.
\end{abstract}

\section{INTRODUCTION}

In general, globalization refers to a process that encompasses the causes, course, and consequences of transnational and transcultural integration of human and non-human activities with a number of consequences either good or bad related to educational, political, cultural aspects, and so on (Al-Rodhan, 2006, as cited in Harwati, 2013). The emergence of western-dominated international culture, the erosion of national identity, traditional values, languages, and cultures in Asian countries, therefore, can be the examples of negative consequences. Indonesia then needs to preserve and promote local cultures, for example local languages. Such an attempt can be initiated through educational sector. However, it seems that the importance of preserving local languages at an elementary school level in Indonesia is a big unaddressed problem. Most research regarding language and education focused more on the popularity of English among young generation, especially those coming from upper-middle social classes.

As this study is focused on local language preservation at an elementary school level, its result will then improve
Indonesian's capacity and potential for innovation. Initiating a research project on the critical importance of preserving local languages and incorporating such languages into curriculum for all students will be beneficial for Indonesia in terms of cultural sensitivity and awareness development. The research problem that emerges is: What is the story of the teachers who tried to preserve Javanese language in the global era? More specifically, this study aims to discuss Javanese language preservation at SD Bernardus, Tritis, an elementary school in Pakem, one of the regions in Yogyakarta. This elementary school is located in a rural area, position Javanese language as a compulsory subject, and has homogenous student population and most of them come from lower social class backgrounds. With this study, the author wish to be actively involved in efforts to develop Indonesian education sector and be able to contribute to the betterment of basic education in Indonesia, especially in rural areas, such as Tritis, which has been chosen as a location for conducting research. The author also believes that this study could be used as an essential step to enhance further professional interaction, partnerships, and collaborative projects. 


\section{LITERATURE REVIEW}

\section{Theory: Sociolinguistics and Social Change}

Holmes (2001) states that sociolinguistics as a branch of both linguistics and sociology can be defined as the study of the relation between language and society. Jendra (2007) further explains that in sociolinguistics, society (community) is seen as a source of linguistics repertoire. Linguistics repertoire itself can be defined as a group of languages, for example first language, regional or local language, and languages learned in schools mastered by the same speaker. The linguistics repertoire of one speaker is determined by his or her passive and active knowledge of the language varieties within his or her speech community. However, certain communities are unaware of the importance of preserving, protecting, and promoting local languages. Preventing local languages from becoming unknown is, therefore, essential.

Drawing from the above explanation, it can be argued that preserving Javanese language at an elementary school level has a correlation with society as a source of linguistics repertoire.

"Society consists of individuals and they are its only representatives, just as individuals exist only within a society. Individual and social existence are themselves manifest simultaneously, develop at the same time, and change interdependently" (Hauser, 1982, p. 40).

This statement implies that society and individuals are inseparable, without society there can be no individual. Furthermore, individuals within society have agreements on what need to be changed or preserved, including language (verbal and nonverbal), knowledge, beliefs, and also values. In brief, there is a significant alteration related to social structure and cultural patterns through time. This is what we called social change (Leicht, 2013, n.p.). Leicht further explains, "social structure refers to persistent networks of social relationships where interaction between people or groups has become routine and repetitive. Culture refers to shared ways of living and thinking."

Based on the explanation about social change, it can be concluded that local languages (such as Javanese language), as one of the most important elements of culture, will be preserved, promoted or even neglected, depends on the agreement among individuals within society.

\section{Previous Studies}

The early studies in the area of Javanese language preservation have emphasized on why and how Javanese language is still used among society in Blora, Central Java (Marnoto, 2007; Setyaningsih, 2010). More specifically, the two previous studies focused more on describing efforts in maintaining Javanese language viewed from sociolinguistics perspective. These studies reported that Javanese language preservation in Blora is related to loyalty, ideology, and tradition. Hadiati (2013), on the other hand, was interested in analyzing the use of Javanese language among young generation in Kebumen, Central Java. More specifically, she has undertaken a case study to examine Javanese language used by Orion community and how members of the community attempt to increase their own opportunities to use traditional vocabulary in their conversation. Here, sociolinguistics is also used as a theory. More recently, Suherman (2015), focused on identifying and describing the form of variations in language use in Gerem village communities. He explained the viability of Serang Java language and efforts in maintaining the language. He then concluded that Serang Java language still survives. It is used as a means of communication, through cultural activities and local wisdom. This study is framed within an ethnographic perspective and theory of motivation is applied to answer the research question. In addition, Nurani (2015) analyzed the extent to which Javanese language matters for the Javanese people's identity in Yogyakarta and how the language planning and policy mechanism works to foster Javanese language. It can be concluded therefore that the previous studies, which have emphasized more on the use of Javanese language in certain communities ignored the importance of teaching and learning at an elementary school level in order to preserve Javanese language. Indeed, preserving and introducing linguistic diversity and cultural pluralism to pupils, is vital.

\section{METHOD}

\section{Narrative Research Design}

Ehrlich, Flexner, Carruth, and Hawkins (1980, p. 442, as cited in Creswell, 2005, p. 474) explain, "the term narrative comes from the verb to narrate or to tell (as a story) in detail". In narrative research designs, researchers have to describe individual experiences and then write those experiences in detail. Narrative research design with purposeful sampling was chosen to comprehend teachers' point of view on globalization and the importance of preserving Javanese language. The author has described the lives of two teachers from SD Bernardus, Tritis, collected and told stories about their lives, and written narratives of their experiences. The data were gathered through the collection of stories, reporting individual experiences, and discussing the meaning of those experiences for the teachers. The hypothesis was if Javanese language continues to be taught during elementary school level as a compulsory subject then students would learn local cultural values.

\section{Data Collection, Data Analysis, and Ethical Issues}

The author has undertaken a fieldwork in Tritis, Purwobinangun, Pakem, Yogyakarta, for about two weeks. There were two main steps of the fieldwork, namely: (1) Identifying characteristic, which was, Javanese language preservation at an elementary school level; (2) Finding sites and individuals that display different dimensions of that characteristic, such as an elementary school with different characteristics to preserve Javanese language. The participants and sites based on places and people that can best help to understand the central phenomenon had been identified. The fieldwork is essential to be undertaken in order to comprehend teachers' reflection and teachers' knowledge, and also bring teachers' voices to the forefront by empowering teachers to talk about their ex- 
periences, focusing on the micro-analytic picture, individual stories. In other words, capturing the lives of teachers as professionals is vital. Through interview or informal conversations, the author has gathered stories (field texts or raw data), which were then analyzed for meaningful interpretation.

The data gathered were analyzed through several steps. Coding, as the first important stage in analyzing data had been done to organize the text of the interview transcripts and discover themes, which could not be seen directly in the texts in the beginning of analysis. The bottom-up coding was used. This term refers to an idea of coding which moves "from raw text to research concerns in small steps, each step building on the previous one" (Auerbach, \& Silverstein, 2003, p. 35). These steps were: (1) gathering raw text, (2) gathering relevant text, (3) repeating ideas, (4) discovering themes, (5) theoretical constructs, (6) theoretical narrative, and (7) research concerns (ibid). It means that raw text is the lowest level, whereas research concerns is the highest level.

The author then read through the texts and cut them down if necessary in order to select relevant text. This term refers to the text, which has a relation with the research concern (Auerbach and Silverstein, 2003). After selecting the relevant text, the author needed to choose the text, which had similar ideas. During the process of data collection it was possible that different participants had similar utterances to express the same ideas (repeating ideas). By understanding the repeating ideas, it was easier to find out the themes. These terms referred to repeating ideas, which had something in common (Auerbach, \& Silverstein, 2003). These themes were then grouped and known as theoretical constructs. These theoretical constructs were organized into a theoretical narrative, which concluded what I had understood about the research concern.

The research concern was to explore the teachers' opinions and experiences of teaching Javanese language. The author had attempted to find the correlation between their concerns and her concern. Through the bottom-up coding it was easier to find that connection. It is possible, however, that the participants have concerns that do not prove to be related to ours. Auerbach and Silverstein (2003) suggest that when this problem occurs, it will be better if the researcher includes the participants' concerns even though they do not fit into the theoretical framework. They can form the basis of the next research project. After coding process, it is important to describe the data through helping readers to visualize setting so that they could almost feel the situation. A convincing descriptive passage was therefore essential.

The last stage of the research was interpretation of the patterns seen and heard by the participants. It was vital in the attempt to reach some conclusions about information gathered. In order to avoid subjectivity, evidence for the interpretation was used. As Auerbach and Silverstein (2003) state that:

"You must be able to support your interpretation with data (i.e., examples of text), so that other researchers can understand your way of analyzing it. If your interpretation is supported by the data, then it is valid, even if there are other ways to interpret the same data" (p. 32).
The above statement also can be used to answer the question about validity and reliability in qualitative methodology.

Honoring research sites and participants is important. Creswell (2005, p.171) maintains that "data collection should be ethical and it should respect individuals and sites". In brief, explaining the purpose, aims, the use of results of the study, and the amount of time needed to gather data is important. The author has given a letter to the participants with information about this study and asked them to sign a consent form. Permission from SD Bernardus, Tritis was also essential. An official letter had been sent to obtain an approval to conduct this study. Furthermore, the school principal had become a gatekeeper. She provided entrance to the site and helped the author to locate the participants, for instance when the author intended to conduct an interview. In other words, this study implemented 'overt' access, which means that this access is "based on informing subjects and getting their agreement, often through gatekeepers" (Silverman, 2001, p. 57).

\section{RESULTS AND DISCUSSION}

The interview results with two interviewees, Mrs. Sugesti and Ms. Primitiva Rindi will be presented. Both of them have agreed to be mentioned in this study. The interview results are grouped into two major themes:(1) the challenges faced in teaching Javanese language and (2) the creative ways to teach Javanese language in the classroom.

\section{The Challenges Faced in Teaching Javanese Language}

From the interview, it is found that there are two main challenges faced in teaching Javanese language. The first challenge is that many students are unaware that there are a variety of forms to use in addressing another. In the study by Wardhaugh (2006, p. 260) "many languages have a distinction corresponding to the tu-vous (T/V) distinction in French, where grammatically there is 'a singular you' $t u(\mathrm{~T})$ and 'a plural you' vous". The T form is considered as a familiar form, whereas the $\mathrm{V}$ form is the polite one. Javanese language has such a distinction, the kowe/panjenegan $(\mathrm{K} / \mathrm{P})$, distinction. Kowe is a familiar form and panjenengan is used to show respect and politeness. The first interviewee states:

Sometimes the students use kowe to address teachers as the $K$ form is commonly applied within their families. This is the reason why I then focus more on giving examples of how and when the students can use the K/P form (Mrs.Sugesti, Interview)

Holmes (2001) argues that being polite is very complicated thing to most speakers in any language. Indeed, speakers have a freedom to choose their own speech forms, such as humorous, formal, informal, etc. In general, however, individuals within society have agreements on how they have to formulate messages they want to communicate. As Gumperz (1964, as cited in Busch, 2012) explains, we need to be aware of the social etiquette of language choice.

The second challenge is related to teaching and learning materials. The second interviewee maintains: 
It is difficult for me to find an effective approach as the textbooks provided emphasize more on theory without any practical and real lifetime situations (Ms. Rindi, Interview)

Smrekar (1994, as cited in Soto, 1999, p. 5) states that it is important to "arrange the classroom with spaces that encourage social interaction”. So providing many opportunities for students to communicate using Javanese language in the classroom is vital.

However, the interviewees believe that these challenges can be viewed from a different perspective, as an opportunity to develop their creativity. This issue will be examined more fully in succeeding part of this study by looking at creative ways of teaching that have been applied to the classroom. Furthermore, the interviewee argues:

It is my duty to convince the students that learning and preserving Javanese language is crucial. Living in the global era does not necessarily mean that we ignore local cultures, values, and languages (Mrs. Sugesti, Interview)

This statement is in line with Ravindranath (2009), who explains that maintaining local languages is important, as a language is "a marker of community identity" (p.9).

Considering that a certain language is seen as a community identity, the teachers and students at SD Bernardus Tritis as a speech community and a source of linguistics repertoire, should, therefore, be able to maintain Javanese language. As Jendra (2007) argues that in sociolinguistics it is hoped that speech communities are able to maintain and protect their languages. Actually, the society in Tritis has been attempting to maintain Javanese language. The language is even used as a means of communication through cultural activities, such as merti bumi. "The term merti bumi came from Javanese words, which are, petri/memetri (maintain) and bumi (earth)" (Harwati, 2013, p. 32). This notion can then be defined as maintaining mother earth or nature, a ritual to maintain the harmony between nature and human beings. The ritual of merti bumi is held regularly on the Islamic New Year's eve and has been handed down from generation to generation. In other words, the attempt to preserve Javanese language through cultural activities is in line with Hauser (1982) and Leicht (2013), who explain that there are always agreements within society on how and what elements of culture need to be maintained, changed, or promoted. In relation to the ritual of merti bumi, the interviewees in this study believe that teaching Javanese language can be considered as an initial step to introduce local cultural values to the students. Here, the author is not attempting to predict the future of Javanese language or even Javanese traditional ceremonies. It is important to note, however, that as young generations, the students at SD Bernardus need to be aware of their duty to learn, practice, and preserve the ritual.

In support of the above explanation, the Diagram 1 from the Indigenous Remote Communications Association (IRCA) in Australia can be used as a model to comprehend the interconnectedness of Javanese language with culture, family, country, and kinship for Javanese people.

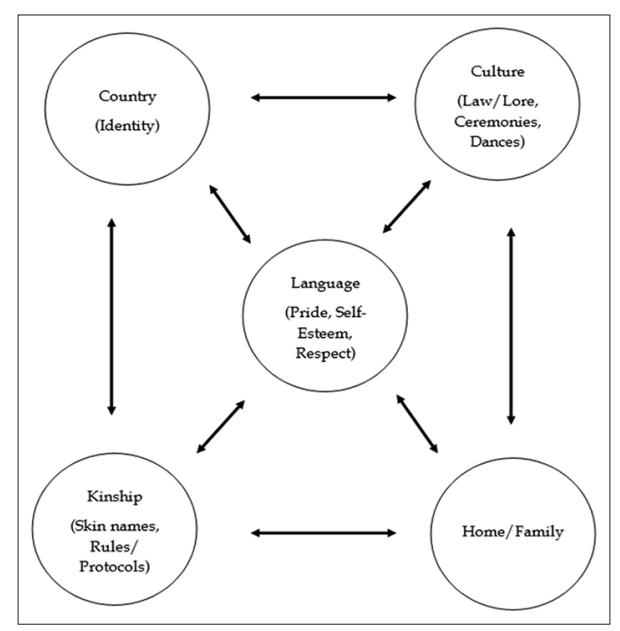

Diagram 1. Diagrammatic Interpretation of the Interconnectedness of Language (Diagram by Lionel James)

\section{The Creative Ways to Teach Javanese Language in the Classroom}

Javanese language is a compulsory subject for all students $\left(1^{\text {st }}-6^{\text {th }}\right.$ grade, two hours per week) and it was mentioned previously that the teaching and learning materials provided did not encourage social interaction. The teachers at SD Bernardus Tritis then found creative ways of teaching Javanese language. From sociocultural theory of language and learning perspective, it can be said that they implemented what Vygotsky (1978, as cited in Norton and Toohey, 2011) explains that learning is a social process and students should be actively involved in various activities using cultural tools.

For their fourth, fifth, and sixth graders, for instance, the teachers created realia to improve students' understanding of vocabulary. More specifically, they prepared traditional stories to be read and help the students to identify vocabulary that may be unfamiliar to them. The interviewee states:

The students are then asked to work in cooperative groups and retell the story. I also use photographs with certain topics, such as ethnic items. Here, Javanese traditional clothes are chosen as realia to develop the students'vocabulary and give them cultural experiences (Mrs. Sugesti, Interview)

Furthermore, collaborating with other teachers, such as art and culture teachers is considered as another creative way of teaching Javanese language. With their first, second, and third graders, the teachers attempted to introduce traditional games, such as congklak/dakon, which is known by different names from region to region in Indonesia. Historically, young girls of Javanese nobility played this game but nowadays it is widely played by the common people. This game is played by two persons using equipment with fourteen small holes and two big holes, which are made for filling them with seven small stones. In addition, Javanese traditional songs, such as Gambang Suling and Lir-Ilir, are also introduced to the students. Here is a Picture 1 of the equipment of congklak/dakon.

Evidently, the teachers tried to apply both formal and informal patterns of learning to the classroom. In one developmental study (Bloomaert \& Backus, 2012) state that such 


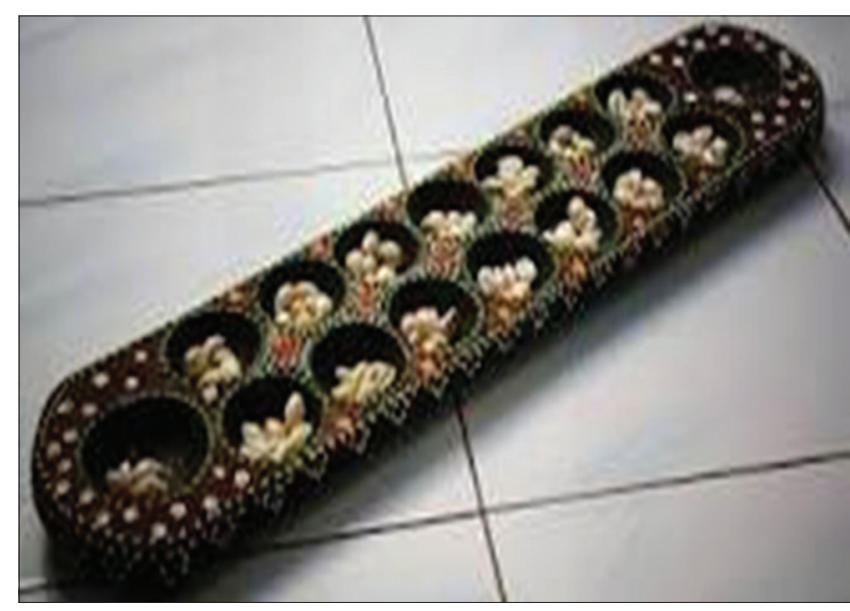

Picture 1. The Equipment of Congklak/Dakon

patterns of learning enable students to understand that there are different language varieties, styles, and registers.

The attempt to preserve Javanese language and culture at SD Bernardus Tritis is supported by the school principal. Such supports help the students to develop a sense of belonging and a cultural identity. As the interviewee explains:

Every Friday, for example, it is obligatory for all students to address their teachers using Javanese language. In addition, once a month they conduct a flag ceremony in Javanese language and all participants (both leader and audiences) must wear Javanese traditional clothes (Ms. Rindi, Interview)

In 2017, the local government (Sleman Regency) acknowledged that traditional games and theater competition for elementary school students was an effective means in achieving social aims. Competition is recognized as a tool for emotional and social intelligence development. On August, the local government then initiated such kind of a competition and SD Bernardus Tritis has participated in it. The competition taught the students to bring their best effort, manage their nerves, and drove them to learn and perform at a higher level. It also can be said that through this competition, the teachers wanted to give the students a larger space to learn Javanese language and culture in informal patterns.

Drawing from the above discussion, it can be concluded that the local government has a desire to preserve and promote Javanese language and culture. Initiating traditional games and theater competition is in line with Ricento (1994, in Brown, 2000,p. 194) who explains that:

"Within the United Nations, the Universal Declaration of Linguistics Rights has endorsed the right of all people to develop and promote their own languages and to offer children access to education in their own languages (as cited in Harwati, 2012, p. 48)".

Indeed, the local government does not require elementary schools in Sleman to use Javanese as a language of education or instruction. It can be argued, however, that a greater access is given to students to learn Javanese language and culture through the competition. In addition, both the teachers and the local government can be considered as agents of society, active representatives to maintain and promote a local language as one of elements of culture.

\section{CONCLUSION}

Local languages, as one of important elements of culture, need to be preserved and promoted in order to manage the possible negative effects of globalization. The central phenomenon upon which this was based relates to the creative ways of teaching Javanese language at SD Bernardus, Tritis, Pakem, Sleman, Yogyakarta. Indeed, the teachers at SD Bernardus have introduced new forms of Javanese language teaching method and they also play an important part in spreading these trends. More specifically, the phenomena addressed included the use of realia, traditional games and songs to teach Javanese language and the support from the school principal as well as the local government to preserve this local language. The elementary school located in a rural area and has a desire to maintain local values, such SD Bernardus, clearly has been attempting to give a greater access to the students to learn Javanese language and culture through formal and informal patterns. It is hoped that the students will be able to learn local culture values. As young generations, they will become agents of society who decide what elements of culture should be maintained.

It was also mentioned earlier that this study is significant in terms of filling the gap in research in the area of Javanese language teaching and learning due to limited literature on this area in Indonesia. At this stage, it can reasonably be assumed that this topic might not be regarded as a major problem. Knowledge of effective teaching strategies is vital in terms of providing an in-depth understanding of how elementary schools can deal with the possible negative impacts of globalization. Further study in this area in different aspects would be beneficial in helping schools and local government as part of speech communities to preserve and promote Javanese language.

\section{REFERENCES}

Auerbach, C.F., \& Silverstein, L.B. (2003). Qualitative data: an introduction to coding and analysis. New York: New York University Press.

Blommaert, J., \& Backus, A. (2012). Superdiverse repertoires and individual. In I. Saint-Jacques \& J.J. Weber (Eds.), Multimodality and multilingualism: Current challenges for educational studies (pp. 1-32). Rotterdam: Sense Publishers.

Busch, B. (2012). The linguistic repertoire revisited: applied linguistics advance access. Oxford: Oxford University Press.

Creswell, J. W. (2005). Educational research: planning, conducting, and evaluating quantitative and qualitative research $\left(2^{\text {nd }}\right.$ ed.). University of Nebraska-Lincoln: Pearson Education.

Hadiati, P. (2013). Pergeseran dan pemertahanan bahasa jawa pada komunitas band di studio orion kabupaten kebumen. Jurnal Pendidikan, Bahasa, Sastra, dan Budaya Jawa Universitas Muhammadiyah Purworejo, 3(6), 175-264.

Harwati, L.N. (2012). Will english coexist with the indonesia language? Asian EFL Journal Professional Teaching Articles (Special CEBU Issue), 61, 41-51. 
Harwati, L. N. (2013). Preserving local culture in the globalization era through merti bumi: a project report. Asian Journal of Literature, Culture, and Society, (7)2, 28-34.

Hauser, A. (1982). The sociology of art (Kenneth J. Northcott trans.). Chicago: The University of Chicago Press.

Holmes, J. (2001). An introduction of sociolinguistics ( $2^{\text {nd }}$ ed.).Edinburgh Gate: Pearson Education.

Indigenous Remote Communication Association (IRCA). (n.d). Diagrammatic interpretation of the inter-connectedness of language. Retrieved from www.aphref. aph.gov.au/House/committee/atsia/languages/report/diagram1.png.

Jendra, I. W. (2007). Sosiolinguistik teori dan penerapannya. Surabaya: Paramita.

Leicht, K.T. (2013). Social change. Retrieved from http:// www.oxfordbibliographies.com/view/document/obo9780199756384/obo-9780199756384-0047.xml.

Marnoto. (2007). Penggunaan bahasa dalam ranah keluarga muda jawa di kabupaten blora. Program Studi Pendidikan Bahasa Indonesia, Program Pascasarjana, Universitas Negeri. Semarang: Unpublished thesis.

Nekcovei, D.L., Smekar, J.L., \& Soto, L.D. (1999). Preserving home languages and cultures in the classroom: challenges and opportunities. In P.A. Dicerbo (Ed.)., Directions in language \& education national clearing house for bilingual education, 13 (pp.1-8).
Nurani, L.M. (2015, August). Changing language loyalty and identity: an ethnographic inquiry of societal transformation among the javanese people in yogyakarta, indonesia. Arizona State Univeristy: Dissertation. Retrieved from https://repository.asu.edu.

Norton, B., \& Toohey. K. (2011). Identity, language learning, and social change. Cambridge: Cambridge University Press.

Ravindranath, M. (2009). Language shift and the speech community: sociolinguistic change in a garifuna community in belize. University of Pennsylvania: Dissertation. Retrieved November 15, 2016, from http://repository.upenn.edu/edissertations/33.

Setyaningsih, N. (2010). Pemertahanan bahasa jawa samin di kabupaten blora. A paper presented at Seminar Nasional Pemertahanan Bahasa Nusantara, Magister Linguistik PPS UNDIP Semarang.

Silverman, D. (2001). Interpreting qualitative data: methods for analyzing talk, text and interaction ( $2^{\text {nd }} \mathrm{ed}$.). London: SAGE Publications Ltd.

Suherman. (2015). Variasi penggunaan bahasa dan pemertahanan bahasa jawa serang di cilegon provinsi banten. Edusentris, Jurnal Ilmu Pendidikan dan Pengajaran, 2(3), 175-264.

Wardhaugh, R. (2006). An introduction to sociolinguistics ( $5^{\text {th }}$ ed.). Victoria: Blackwell Publishing. 